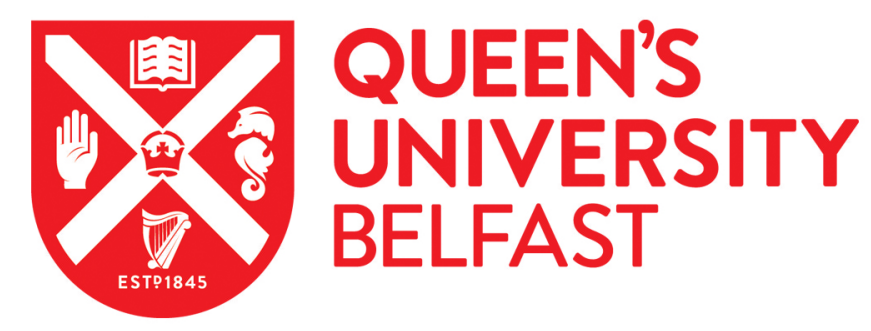

\title{
Review of virtual power plant applications for power system management and vehicle-to-grid market development
}

Jin, T-H., Park, H., Chung, M., Shin, K-Y., Foley, A., \& Cipcigan, L. (2016). Review of virtual power plant applications for power system management and vehicle-to-grid market development. The Transactions of the Korean Institute of Electrical Engineers, 65(12), 2251. https://doi.org/10.5370/KIEE.2016.65.12.2251

\section{Published in:}

The Transactions of the Korean Institute of Electrical Engineers

Document Version:

Publisher's PDF, also known as Version of record

Queen's University Belfast - Research Portal:

Link to publication record in Queen's University Belfast Research Portal

Publisher rights

Copyright 2016 The Korean Institute of Electrical Engineers.

This is an Open-Access article distributed under the terms of the Creative Commons Attribution Non-Commercial License

(http://creativecommons.org/licenses/by-nc/3.0/) which permits unrestricted non-commercial use, distribution, and reproduction in any medium, provided the original work is properly cited.

\section{General rights}

Copyright for the publications made accessible via the Queen's University Belfast Research Portal is retained by the author(s) and / or other copyright owners and it is a condition of accessing these publications that users recognise and abide by the legal requirements associated with these rights.

Take down policy

The Research Portal is Queen's institutional repository that provides access to Queen's research output. Every effort has been made to ensure that content in the Research Portal does not infringe any person's rights, or applicable UK laws. If you discover content in the Research Portal that you believe breaches copyright or violates any law, please contact openaccess@qub.ac.uk. 


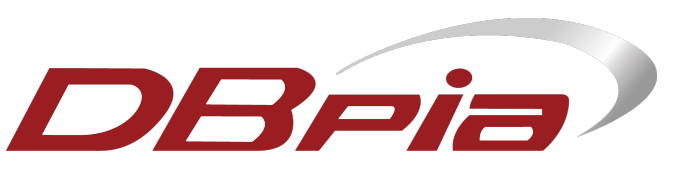

\section{Review of Virtual Power Plant Applications for Power System Management and Vehicle-to- Grid Market Development}

전력시스템 관리 및 Vehicle to Grid 전력시장 개발을 위한 가상발전소의 활용방안

저자 $\quad$ Tae-Hwan Jin, Herie Park, Mo Chung, Ki-Yeol Shin, Aoife Foley, Liana Cipcigan

(Authors)

출처

(Source)

발행처

(Publisher)

URL

APA Style

이용정보

(Accessed)
전기학회논문지 65(12), 2016.12, 2251-2261 (11 pages)

The transactions of The Korean Institute of Electrical Engineers 65(12), 2016.12, 2251-2261

(11 pages)

대한전기학회

The Korean Institute of Electrical Engineers

http://www.dbpia.co.kr/Article/NODE07067064

Tae-Hwan Jin, Herie Park, Mo Chung, Ki-Yeol Shin, Aoife Foley, Liana Cipcigan (2016). Review of Virtual Power Plant Applications for Power System Management and Vehicle-toGrid Market Development. 전기학회논문지, 65(12), 2251-2261.

영남대학교

$165 . * \star * .158 .150$

2016/12/19 14:06 (KST)

\section{저작권 안내}

$\mathrm{DBpia}$ 에서 제공되는 모든 저작물의 저작권은 원저작자에게 있으며, 누리미디어는 각 저작물의 내용을 보증하거나 책임을 지지 않습니다. 그리고 DBpia에서 제공되는 저작물은 DBpia와 구독계약을 체결한 기관소속 이용자 혹은 해당 저작물의 개별 구매자 가 비영리적으로만 이용할 수 있습니다. 그러므로 이에 위반하여 DBpia에서 제공되는 저작물을 복제, 전송 등의 방법으로 무단 이용하는 경우 관련 법령에 따라 민, 형사상의 책임을 질 수 있습니다.

\section{Copyright Information}

Copyright of all literary works provided by DBpia belongs to the copyright holder(s)and Nurimedia does not guarantee contents of the literary work or assume responsibility for the same. In addition, the literary works provided by DBpia may only be used by the users affiliated to the institutions which executed a subscription agreement with DBpia or the individual purchasers of the literary work(s)for non-commercial purposes. Therefore, any person who illegally uses the literary works provided by DBpia by means of reproduction or transmission shall assume civil and criminal responsibility according to applicable laws and regulations. 
ISSN 1975-8359(Print) / ISSN 2287-4364(Online)

The Transactions of the Korean Institute of Electrical Engineers Vol. 65, No. 12, pp. 2251 2261, 2016

http://dx.doi.org/10.5370/KIEE.2016.65.12.2251

\title{
전력시스템 관리 및 Vehicle to Grid 전력시장 개발을 위한 가상발전소의 활용방안
}

\author{
Review of Virtual Power Plant Applications for Power System Management and \\ Vehicle-to-Grid Market Development
}

\author{
진 태 환** 박 혜 리 ${ }^{* *}$ · 정 모* · 신 기 열 ${ }^{*} \cdot$ Aoife Foley $^{* * *} \cdot$ Liana Cipcigan ${ }^{\S}$ \\ (Tae-Hwan Jin · Herie Park · Mo Chung · Ki-Yeol Shin · Aoife Foley · Liana Cipcigan)
}

\begin{abstract}
The use of renewable energy sources and energy storage systems is increasing due to new policies in the energy industries. However, the increase in distributed generation hinders the reliability of power systems. In order to stabilize power systems, a virtual power plant has been proposed as a novel power grid management system. The virtual power plant plays includes different distributed energy resources and energy storage systems. We define a core virtual power plant technology related to demand response and ancillary service for the cases of Korea, America, and Europe. We also suggest applications of the proposed virtual power plant to the vehicle-to-grid market for restructuring national power industries in Korea.
\end{abstract}

Key Words : Virtual power plant, Demand response, Auxiliary service, Operating reserve, Frequency control, Power market liberalization, Vehicle-to-grid

\section{Introduction}

There have been active endeavors to change national power industries in Korea, such as electricity industry restructuring in January 1999, and the national energy plaining for the new energy industry in 2030. As a result, government, academic and research institutes can provide a new management plan that meet stable and reliable power supply systems with distributed energy resources (DERs) such as renewable energy sources (RESs) and energy storage systems (ESSs). In order to establish this type of new power supply system, different features are needed compared to previous requirements.

While the previous power grid consists of only synchronous generators, it includes different types of distributed energy

† Corresponding Author : School of Mechanical Engineering Yeungnam University, Korea.

E-mail: shinky@ynu.ac.kr

* School of Mechanical Engineering, Yeungnam Uni. Korea.

* Automotive Lighting LED-IT Convergence Education, Yeungnam University, Korea.

***School of Mechanical and Aerospace Engineering, Queen's University of Belfast, UK.

$\S$ Electrical \& Electronic Discipline, School of Engineering, Cardiff University, UK.

Received : October 27, 2016; Accepted : November 28, 2016 resources such as RESs and ESSs in power grid of the present. Also, the previous energy demand that is hard to forecasting and controlling are being a controllable and predictable demand resource, and centralized power grid systems turn into distributed systems such as micro-grid that is grid-connected or islanded. This results in a phase shift from the vertically exclusive power industry to a horizontally competitive structure. In terms of liberalized power generation, transmission, and trade, this approach encourages whole sale and retail market competition. However, the existing state of systems remains technically and institutionally insufficient. There are technical limitations to the operational management of multiple distributed energy resources, and institutional limitations on the free participation of retail firms.

In order to address these problems, we propose a virtual power plant (VPP) as a novel power grid management system. The proposed system links several types of distributed generation as one power plant, and operate the one power plant on demand response and ancillary service in power grid. This paper defines a core technology of the VPP that involves demand response and ancillary service in the Republic of Korea(KOR), the United States of America(USA), and Europe (especially in the UK). We also suggest applications of the proposed VPP to the restructuring of national power industries in Korea. 


\section{Main Program of Power Market Operation}

\subsection{Demand Response}

The Federal Energy Regulatory Commission(FERC) of the US defines "demand response"(DR)as follows [1]:

Change in electric use by demand-side resources from their normal consumption patterns in response to change in the price of electricity, or to incentive payments designed to induce lower electricity use at times of high wholesale market prices or when system reliability is jeopardized.

The main task is to maintain grid reliability and regulate to a stable energy demand pattern by inducing demand reduction during a grid emergency or price instability of the electricity wholesale and retail markets. This requires substantial rewards in order to attract demand resources to the DR.

In Korea, the DR aims to simply reduce energy demand. It concentrates on detaining the customer from joining in the incentive-based DR so as to secure system operation reserves by demand resources.

America is the most active country in terms of DR, and its DR capacity has been increasing as follows: $29.7 \mathrm{GW}$ in 2006 , $37.3 \mathrm{GW}$ in 2008, 53.1 GW in 2010, and 66.4 GW in 2012 [1, 2]. A steady increase in DR of 1.2 to 1.4 times every two years is shown. Peak reduction was achieved at $30.5 \%$ of demand resources in 2012. Moreover, independent grid operators manage the DR by using different programs, and contribute to the potential peak demand reduction as shown in Fig. 1 [1].

An example of an interruptible load DR is shown in Fig. 2. The Responsive Reserve Service of Electric Reliability Council of Texas (ERCOT) has generating capacity and an interruptible load as a resource, and produces and stops producing during a frequency drop.

The program forecasts load resources one day in advance based on the predicted hourly temperature. Next it collects resources and decides to be participating on basis. It shows that demand resources play a role as ancillary service such as frequency control. Both suppliers and consumers can actively participate in the market.

The integration of DR programs on the European grid is progressing more slowly than in the USA, but Europe has plans to solve the grid problems by DR. In order to supply

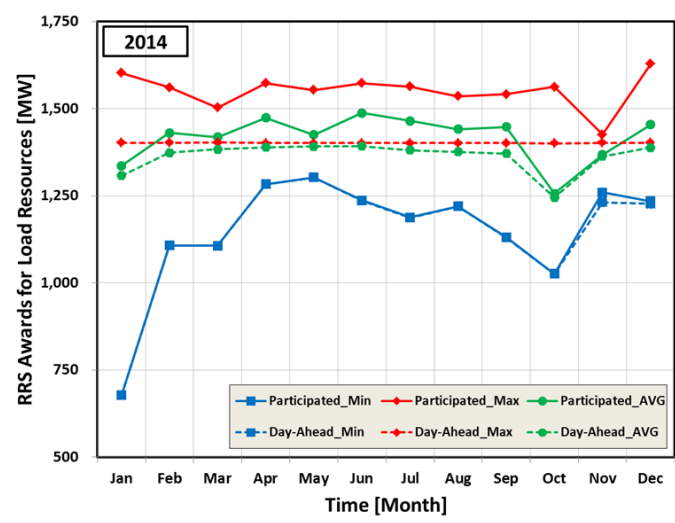

Fig. 2 Responsive Reserve Service's forecasting and participated data in ERCOT.

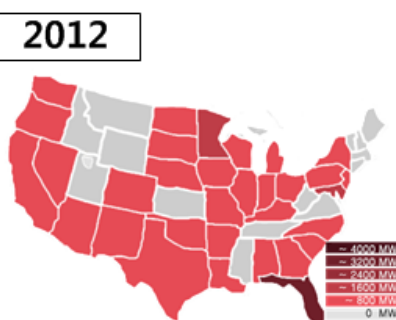

Direct Load Control DR

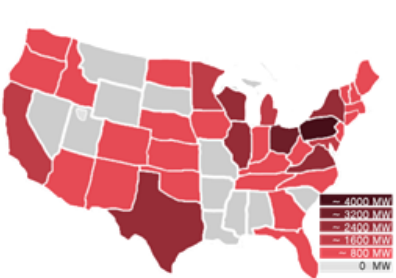

Other Incentive-based DR

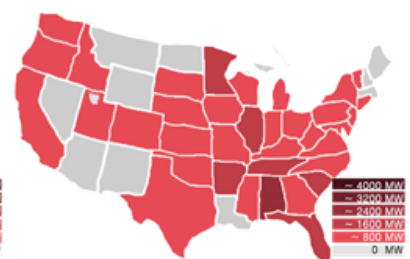

Interruptible Load DR

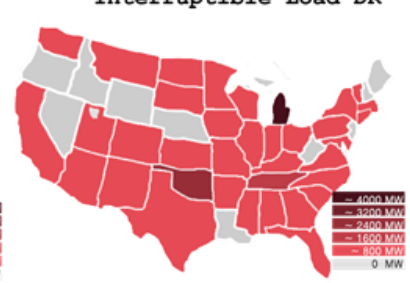

Time-based DR

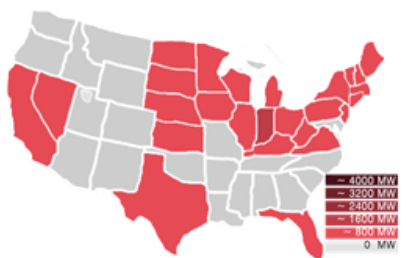

Emergency DR

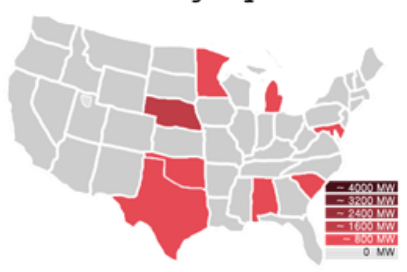

Other DR

Fig. 1 Various programs with potential peak reduction by region in the USA 


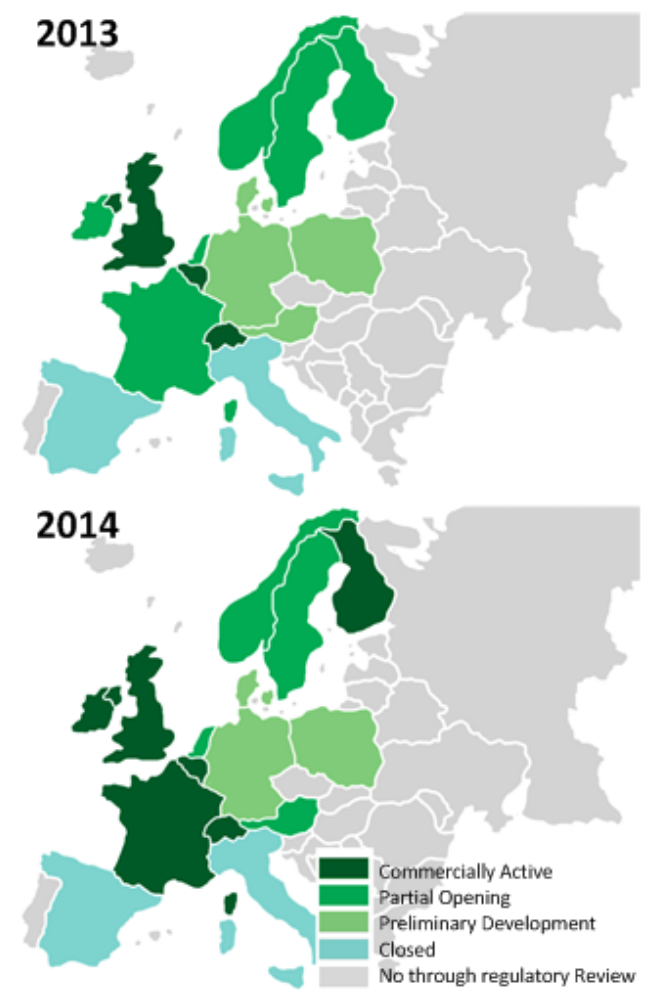

Fig. 3 The expanding DR market in Europe.

renewable energy by up to $20 \%$ of Europe's total energy consumption and reduce CO2 emissions, DR applications are the emergency technology needed in order to retain stable power output and save energy.

Figure 3 shows the DR market in Europe, which expanded in the last two years. Especially in the UK, power generation and the trade market have been totally liberalized. the UK utilizes DR and RES with the help of operation reserves and frequency regulations. For example, as shown in Fig. 4, the UK makes full use of demand resources for a non-spinning reserve.

The Short Term Operating Reserve (STOR) program permits providers that are able to deliver energy within four hours to tender for non-spinning reserve. The program categorizes a demand resource as a committed provider, flexible provider, or premium flexible provider. Each demand resource offers a non-spinning reserve according to season. Table 1 shows a comparison of DR programs from Korea, the USA, and the UK $[1,4-7]$.

\subsection{Ancillary Service}

Ancillary Services are services that ensure reliability, and support the transmission of electricity to customer loads.

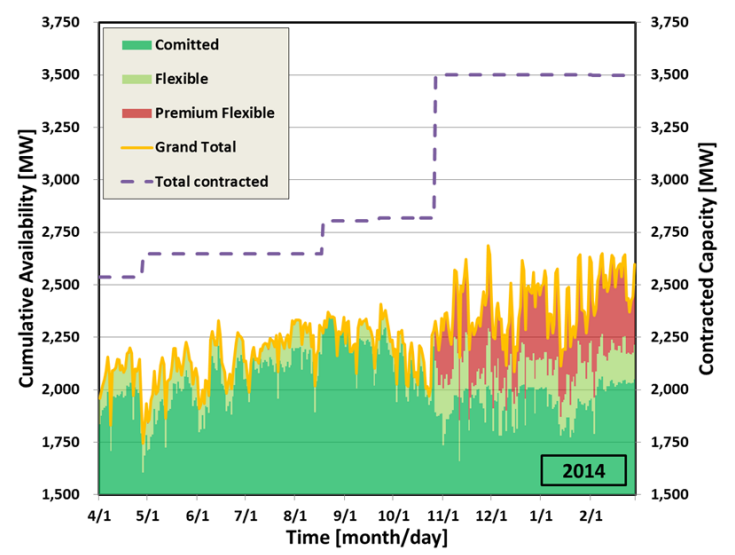

Fig. 42014 to 2015 average daily STOR, availability and contracted.

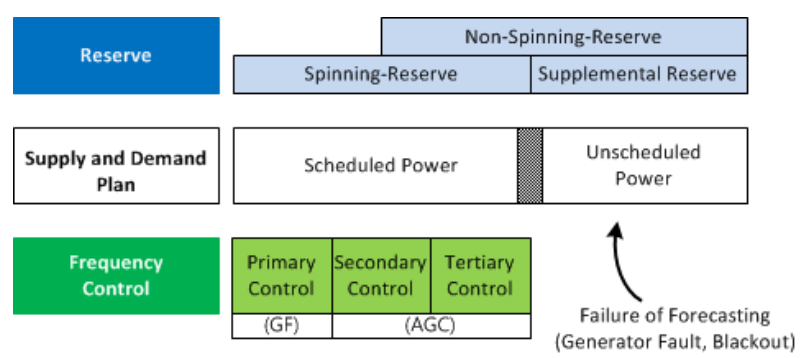

Fig. 5 Concept of ancillary services.

Ancillary services include energy imbalance; operating reserves; contingency reserves; spinning reserves (also known as synchronized reserves, ten-minute spinning, responsive reserves, and operating reserves); supplemental reserves (also known as non-spinning, non-synchronized, ten minute non-synchronous, and planning reserves); reactive supply and voltage control; and regulation and frequency response (also known as regulation reserves, regulation service, up-regulation, and down-regulation).

Figure 5 shows the concept of ancillary services [9]. In grid operation systems, pre-demand supply planning systems have to be established by the grid operators, and secure operation reserves must be established for any grid emergency. Recently, the applications of distributed energy resources have been increased, and DR have been established as alternatives to securing the reserve of auxiliary services.

In Korea, classic methods such as governor-free (GF) and automatic generation control (AGC) are used for frequency regulation and operation reserves. Recently, as shown Fig. 6, substations in Shin Yong-in and Seo An-seong have equipped ESS with batteries of 24 and $28 \mathrm{MW}$, respectively, and use them for frequency regulation. In 2016, a $500 \mathrm{MW}$ class battery energy storage system (BESS) was installed. 
Table 1 Various DR programs in three countries.

\begin{tabular}{|c|c|c|c|c|c|}
\hline Country & Program & Description & $\mathbf{P}^{1}$ & $\mathbf{F}^{2}$ & $\mathbf{B}^{3}$ \\
\hline \multirow{3}{*}{ KOR } & TOU & $\begin{array}{l}\text { Time of use, A rate where usage unit price vary by time period, and where the time } \\
\text { periods are typically longer than } 1 \text { hour within a } 24 \text { hour-day. Its rates reflect the average } \\
\text { cost of generating and delivering power during those time period }\end{array}$ & & & \\
\hline & $\begin{array}{c}\text { Peak } \\
\text { reduction }\end{array}$ & $\begin{array}{l}\text { Program to response to reducing peak demand and to recovery unstable system by } \\
\text { operator's order }\end{array}$ & & & \\
\hline & $\begin{array}{l}\text { Price } \\
\text { reduction }\end{array}$ & $\begin{array}{l}\text { Program to permit customer's tender about demand reduction and price in wholesale } \\
\text { and retail market }\end{array}$ & & & \\
\hline \multirow[b]{5}{*}{ USA } & $\begin{array}{l}\text { Demand } \\
\text { bidding and } \\
\text { buyback }\end{array}$ & $\begin{array}{l}\text { Program which allows a demand resource in retail and wholesale markets to offer load } \\
\text { reductions at a price, or to identify how much load it is willing to curtail at a specific } \\
\text { price }\end{array}$ & & & \\
\hline & $\begin{array}{l}\text { Direct load } \\
\text { control }\end{array}$ & $\begin{array}{l}\text { A demand response activity by which the program sponsor remotely shut down or cycles } \\
\text { a customer's electrical equipment. it are primarily offered to residential or small } \\
\text { commercial customers }\end{array}$ & & & \\
\hline & $\begin{array}{l}\text { Emergency } \\
\text { DR }\end{array}$ & $\begin{array}{l}\text { A demand response program that provides incentive payment to customers for load } \\
\text { reductions achieved during an emergency demand response event }\end{array}$ & & & \\
\hline & IL & $\begin{array}{l}\text { Interruptible load, Electric consumption subject to curtailment or interruption under } \\
\text { tariffs or contracts that provide a rate discount or bill credit for agreeing to reduce load } \\
\text { during system contingencies }\end{array}$ & & & \\
\hline & LCR & $\begin{array}{l}\text { Load as capacity resource, Demand-side resources that commit to make pre-specified } \\
\text { load reductions when system contingencies arise }\end{array}$ & & & \\
\hline \multirow[t]{5}{*}{ 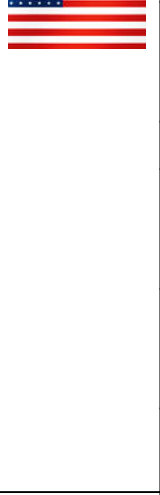 } & $\begin{array}{l}\text { CPP with } \\
\text { load control }\end{array}$ & $\begin{array}{l}\text { Demand-side management that combines direct load control with a pre-specified high } \\
\text { price for use during designated critical peak periods, triggered by system contingencies } \\
\text { or high wholesale market prices }\end{array}$ & & & \\
\hline & TOU & - & & & \\
\hline & $\mathrm{CPP}$ & $\begin{array}{l}\text { Critical peak price, Rate and/or price structure designed to encourage reduced } \\
\text { consumption during periods of high wholesale market prices or system contingencies } \\
\text { by imposing a pre-specified high rate or price for a limited number of days hours }\end{array}$ & & & \\
\hline & RTP & $\begin{array}{l}\text { Real Time Pricing, Rate and price structure in which the retail price for electricity } \\
\text { typically fluctuates hourly or more often, to reflect changes in the wholesale price of } \\
\text { electricity on either a day-ahead or hour-ahead basis }\end{array}$ & & & \\
\hline & PTR & $\begin{array}{l}\text { Peak time rebates allow customers to earn a rebate by reducing energy use from a baseline } \\
\text { during a specified number of hours on critical peak days }\end{array}$ & & & \\
\hline \multirow{4}{*}{ UK } & FFR & $\begin{array}{l}\text { Firm frequency response, Service to be the firm provision of dynamic or non-dynamic } \\
\text { response to changes in frequency and to be designed to compliment other sources of } \\
\text { frequency response and delivers firm availability }\end{array}$ & & & \\
\hline & FCDM & $\begin{array}{l}\text { Frequency control by demand management, Service to provides frequency response } \\
\text { through demand customers to be interrupted when the system frequency transgresses } \\
\text { the low frequency relay setting onsite }\end{array}$ & & & \\
\hline & STOR & $\begin{array}{l}\text { Service for the provision of additional active power from generation and/or demand } \\
\text { reduction }\end{array}$ & & & \\
\hline & FR & $\begin{array}{l}\text { Fast reserve, Service to be used to control frequency changes that might arise from } \\
\text { sudden, and sometimes unpredictable, changes in generation or demand }\end{array}$ & & & \\
\hline \multicolumn{2}{|c|}{ Program Base $\left(\mathrm{P}^{1}\right)$} & Incentive-Based & & & \\
\hline \multicolumn{2}{|c|}{ Function $\left(\mathrm{F}^{2}\right)$} & Attract to reduce load & & & \\
\hline \multicolumn{2}{|c|}{ Bidder's performance $\left(\mathrm{B}^{3}\right)$} & Obligatory & & & \\
\hline
\end{tabular}

Also, a 48 MW class BESS was installed in the Gyeongsan substation. The BESS at Gyeongsan is larger than that of Laurel Mountain (34 MW) in the USA, and is the largest single facility system for frequency regulation in the world.
In America, there are three control methods for frequency regulation, and for maintaining the power demand and supply balance by securing operation reserves. They operate the ancillary services including DR as the greatest DR programs 
in the world. In addition, they offer those services by using multiple distributed energy resources and demand resources by VPP. As shown Fig. 7, according to the Load Response Activity Report published by Pennsylvania-New Jersey-Maryland Interconnection (PJM) in 2015, a monthly average reserve of economic DR as an ancillary service comprised synchronized reserves of $457 \mathrm{MW}$ and regulation reserves of $16 \mathrm{MW}$. They also presented the load reduction methods by water heater (42\%), battery (23\%), HVAC (18\%), generator $(12 \%)$, and so on [10].

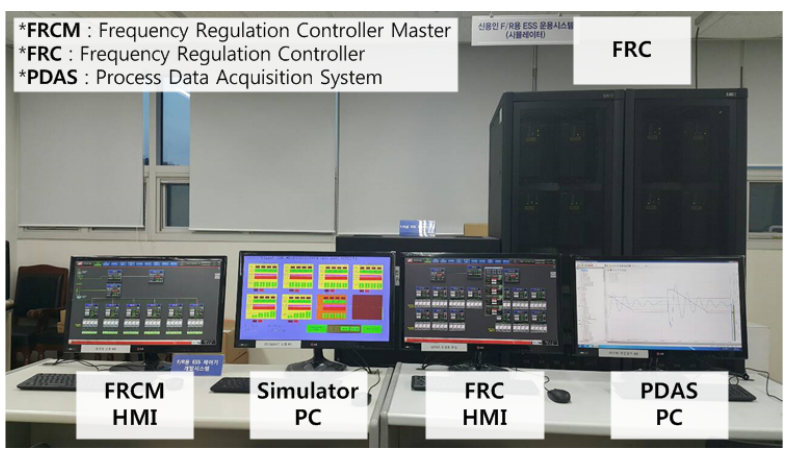

Fig. 6 Frequency regulation controller in ESS operating center in KEPRI.

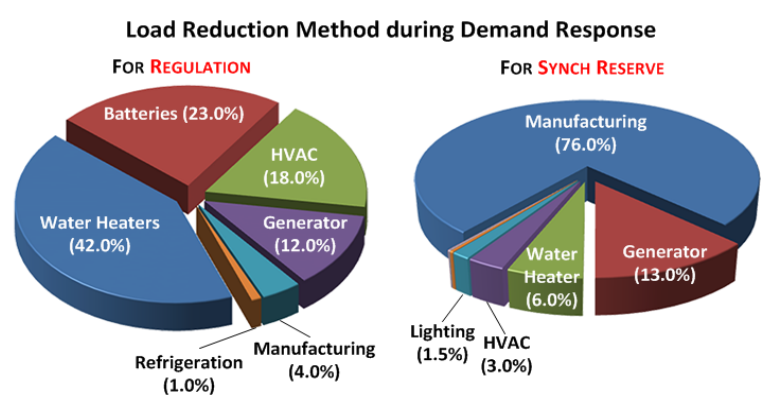

In Europe, the grid is operated by using demand-based plans tendered by customers firmed by liberalized power market. For example, as shown Fig. 8, a transmission network operator and an aggregator operate an ancillary service through a virtual power plant system. The aggregator operates DER and demand resource, and they offer STOR service according to the TNO's dispatching order.

Since prediction errors exist in the market, stable ancillary services are more important compared to other countries. Moreover, a high dependence on wind energy in England requires the help of DR. Therefore, the UK model could be a good example to follow for promoting RES in Korean market of 2030 new energy industry. Table 2 shows a comparison of ancillary service programs in Korea, the USA, and the UK [7-9].

\section{Operation Techniques for DERs and ESS Application Plan}

\subsection{DERs Operation Techniques}

First consider the definitions of DERs and ESS, and the present application plan. Distributed energy resources (DERs) include renewable energy sources, micro-turbines, uninterrupted power supplies as emergency generators, energy conversion and savings technology such as micro-combined heat and power plants, fuel cells, and heat pumps. Each source is difficult individually to participate in grid as a centralized power supply. Recently, the concept of distributed control replacing centralized control through a micro-grid by using demand resources and distributed energy resources for individual demand management has been proposed [12, 13]. Moreover, heat energy obtained by geothermal methods, solar

Fig. 7 Load reduction method by ancillary service in PJM.

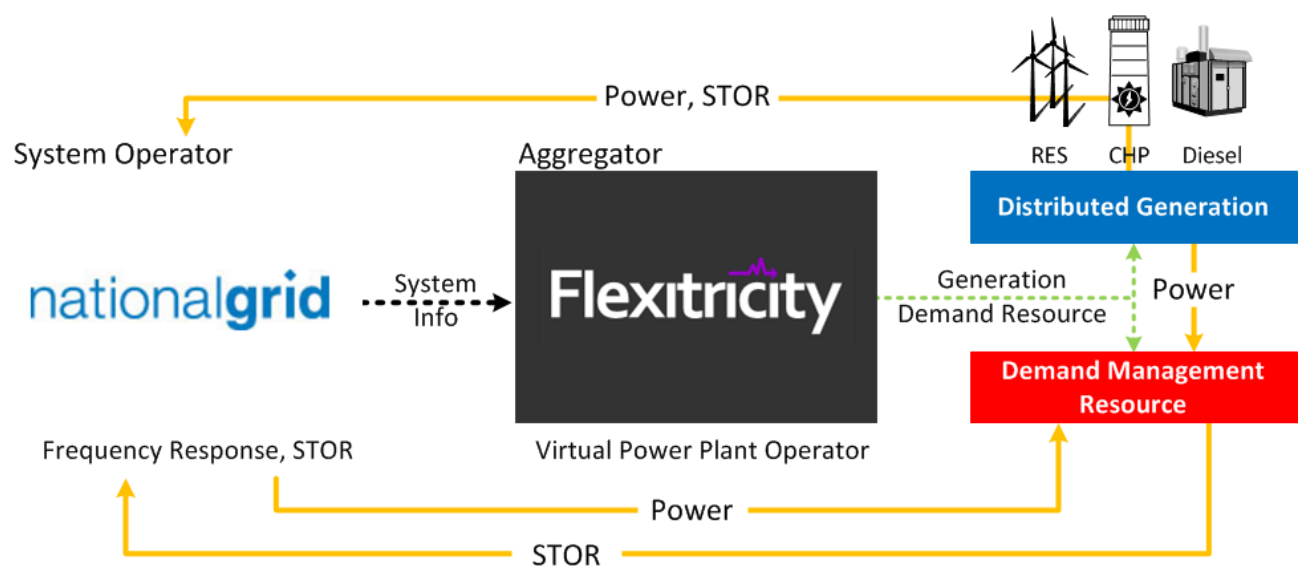

Fig. 8 Flexitricity VPP using DERs and demand resources. 
Table 2 Types and characteristics of ancillary service programs in three countries.

\begin{tabular}{|c|c|c|c|c|c|}
\hline Country & Service & $\begin{array}{l}\text { CAP } \\
\text { (MW) }\end{array}$ & $\begin{array}{c}\text { Response } \\
\text { Time }\end{array}$ & $\begin{array}{l}\text { Duration } \\
\text { Time }\end{array}$ & Sync \\
\hline \multirow{3}{*}{ KOR } & Frequency regulation & 4,000 & $10 \mathrm{~s} / 30 \mathrm{~s}$ & $30 \mathrm{~s} / 30 \mathrm{~m}$ & Sync \\
\hline & Standby/replacement reserve & 2,500 & - & - & - \\
\hline & Self-starting & 2,00 & - & - & Non \\
\hline \multirow{6}{*}{ USA } & Primary control & & $10 \mathrm{~s}$ & $30 \mathrm{~s}$ & Sync \\
\hline & Secondary control & - & $30 \mathrm{~s}$ & $30 \mathrm{~m}$ & Sync \\
\hline & Tertiary control & - & - & - & Sync \\
\hline & Spinning reserve & - & - & - & Sync \\
\hline & Non-spinning reserve & - & - & - & Non \\
\hline & Supplemental reserve & - & - & - & Non \\
\hline \multirow{6}{*}{$\frac{\mathrm{UK}}{1 / \mathrm{V}}$} & Mandatory frequency response & - & - & - & Sync \\
\hline & Firm frequency response & 10 & - & - & - \\
\hline & Frequency control by demand management & 3 & - & - & Sync \\
\hline & BM startup & - & - & - & Non \\
\hline & STOR & 3 & $4 \mathrm{hr}$ & $2 \mathrm{hr}$ & Sync \\
\hline & Fast reserve & 50 & $2 \mathrm{~m}$ & $15 \mathrm{~m}$ & Sync \\
\hline
\end{tabular}

heat pumps, combined heat, and power plants help to alleviate the heating and cooling energy load and reduce transmission and distribution losses [16].

Existing customers have participated in DR programs by simple load shedding or saving energy for loads. New customers could join with ancillary services through energy production by distributed energy resources, or by selling electricity to their power grid [11]. However, in Korea, there is a limitation caused by technical and institutional inadequacy for the services, as shown in the cases of zone electricity operators. The operators equipping DERs into a micro-grid can only sub-serve the grid stability in a grid emergency. Since they could join in DR programs at a certain grid conditions, the granted incentives by using their DERs are less. Greater profits require selling electricity, heat from a heating plant, or from a combined heat and power plant. However, it is not easy to equip all of technical and economic problem at once. In order to solve these problems, business models are needed that permit general consumers to participate in wholesale and retail markets for profit.

Energy storage systems are classified as EES, TES, or flywheel in accordance with the type of stored resources such as electricity, heat, and mechanical power. Recently, ESS based on a BESS battery has been proposed as a solution for frequency regulation and peak demand management [17-19]. Since ESS could have a role in both sides of generation and load by charging and discharging batteries, the load shifting is possibly when performed in a grid, and is helpful in managing stable load patterns and DR.

In addition, the development of battery technologies makes vehicle-to-grid (V2G) possible by using electric vehicles (EVs). V2G is the concept of connecting batteries of the EV with power grids. By considering previous conditions of the demand and supply balance, the EV batteries could be charged and discharged for frequency regulation as one of the ancillary services. However, the installation cost for ESS is high, and its life Time could be reduced because of frequent charge and discharge states. Also, ESS requires other energy sources for charging the batteries in order to cover the huge demand for $\mathrm{EV}$ in the future. And, since the capacity of batteries is limited, a high level control strategy should be established.

\subsection{Virtual Power Plant Applications}

Although the utilization of DERs has many advantages in the operation of power systems as mentioned above, its individual operation has the least impact on power systems $[12,13]$. Figure 9 shows the reason. The figure shows the annual average load curve in Korea from 2012 to 2015 and EV charging load curve 11 states of the USA at 2013, as investigated by the Pacific Northwest National Laboratory. First of all, the annual load curve in Korea shows that the power system has an over-generation risk from 3 to $5 \mathrm{AM}$ and is in a status that must meet $12,000 \mathrm{MW}$ for a ramp $\mathrm{T}$ during five hours (6 to $11 \mathrm{AM}$ ). Until now, the operation of 


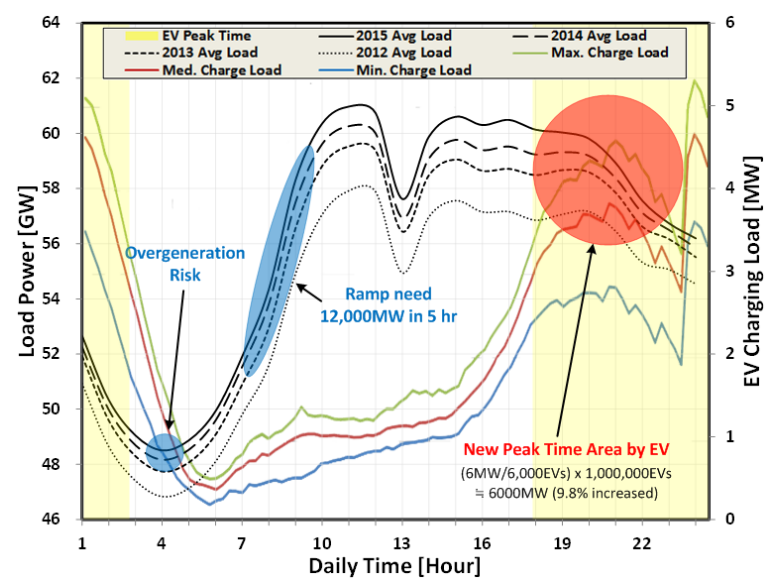

Fig. 9 Annual average load in Korea and EV charging load in USA.

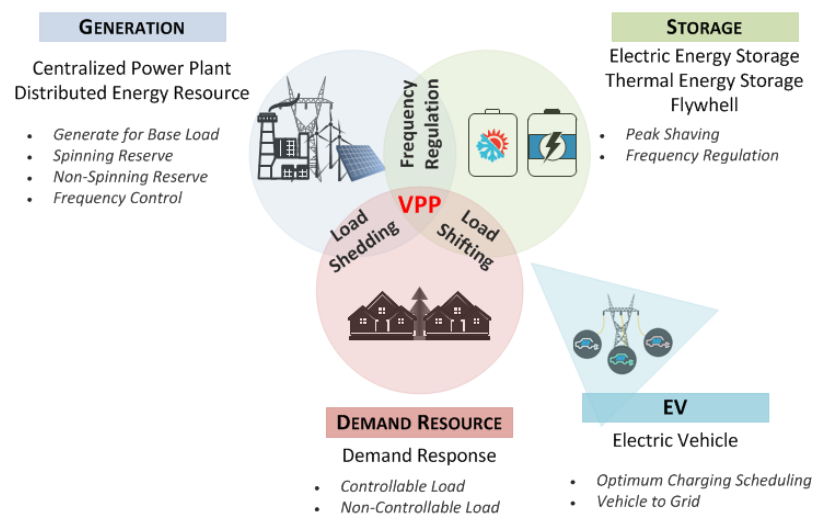

Fig. 10 Main functions of a virtual power plant

the power system has met the regulating capacity through frequency control such as governor free and auto generation control, and synchronized and non-synchronized reserve. However, it could have limitations in increasing annual demand. Moreover, with the increase of EV supplies, EVs will make a new peak demand pattern from 5 PM to 3 AM as shown in the EV charging load curve of the 11 states in the USA.

The Korean government has a plan to supply one million units of EVs by 2030. According to Pacific Northwest National Laboratory, we can guess that there would be a new power demand of 6,000 MW by the supplied EVs, which represents about $9.8 \%$ of the domestic power demand [14]. In this case, it is imperative to equip an energy source that could cover conventional peak demand and new peak demand at a proper condition for stability and reliability of the power system. For that, we could operate one power plant that links to various DERs, instead of individual operation of DERs.

In order to solve the problems of distributed generation,
VPP can be considered. The VPP is a technology to efficiently manage different resources related to generation, storage, and demand resources by using software. It strengthens the flexibility of power grid operation based on Information Communication Technology (ICT), totally managing both supply and demand side resources [15]. Since ICT functions as generation or net load at different $\mathrm{T}$ slots, it involves a virtual concept. When individual DERs link to one system as a virtual power plant, we can explain the functions of this system with Fig. 10. Figure 10 shows the main functions of a combined concept of generation, storage, and demand.

First, we consider a combination of generation and storage. When a storage device is charged by a generator or is discharged, it can decrease its operation rate by operating ancillary services such as frequency control and reserve through a synchronized generator. It can counteract conventional peak demand and new peak demand by EVs. There is also a combination of DERs, such as a renewable energy resource and energy storage system. We can maintain lower transmission losses than those of centralized power plants. In addition, heat and cooling electric load can decreaseas energy conservation technology (such as micro-combined heat and power) generates thermal energy.

Second, we can combine generation and demand. The demand is classified by use in terms of agricultural, residential, commercial, industrial, and campus loads. The demand can also be classified into controllable loads and non-controllable loads. In this case, a demand source plays a role as a generation part, which means that the demand source could decrease the stress of the generation part by load shedding.

Third, there is a combination of storage and demand. When demand sources participate in DR, demand cannot receive electric power. However, demand combined with storage can receive electric power by load shifting As a result, virtual power plants can make extra power and maintain the flexibility of the power system through one concept combined with generation, storage, and demand with the help of regulation, load shedding, and load shifting.

Figure 11 shows an overall system concept of a virtual power plant. A VPP classifies the generation, storage, and demand source for optimizing and managing one aggregated plant. The demands are classified by agricultural, residential, commercial, industrial, and campus loads. Depending on the demand, DERs (such as renewable energy resources, energy conservation, or an energy storage system) are optimized.

An optimized decentralized power system such as a micro-grid can supply extra power to conventional power 


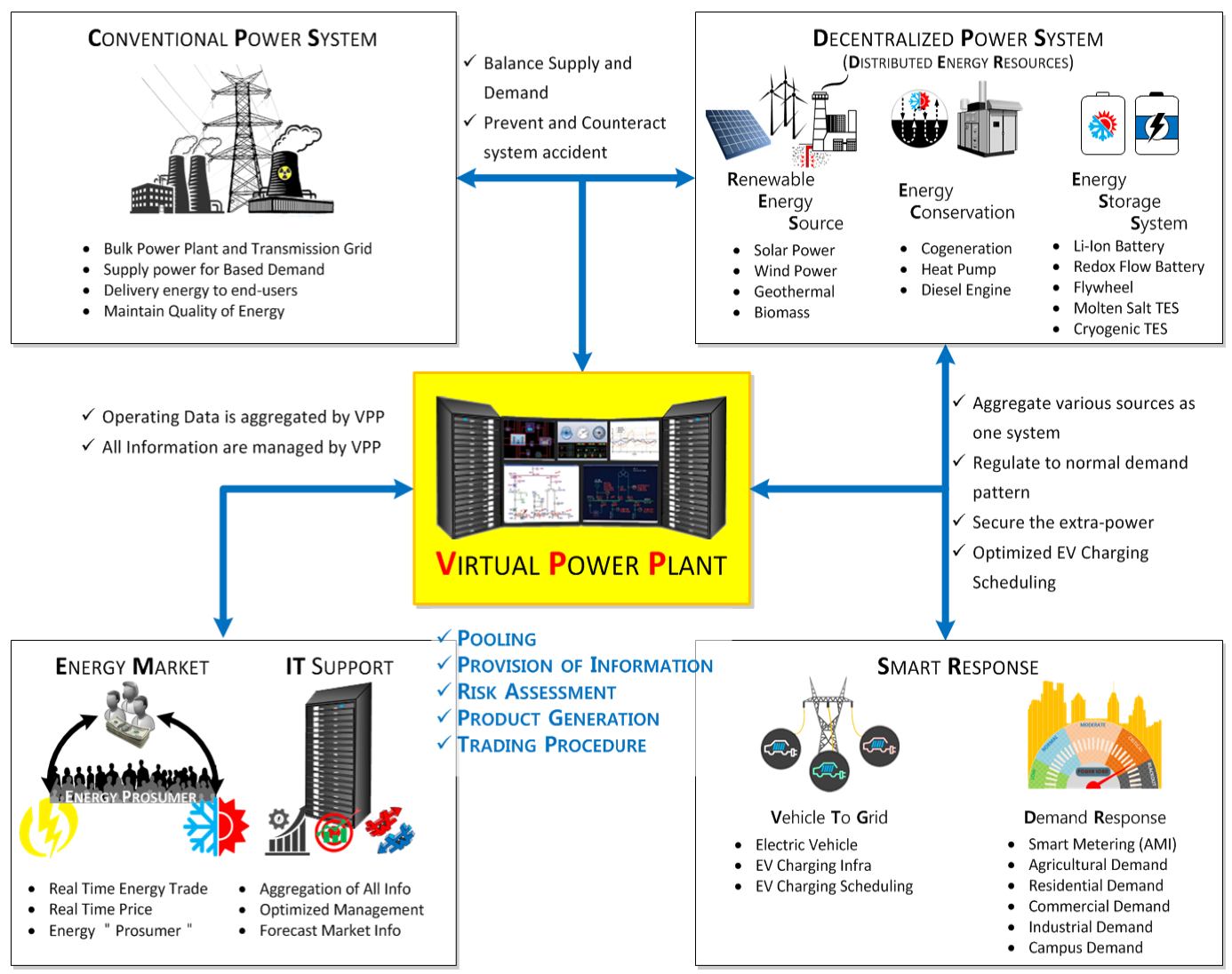

Fig. 11 Overall system concept and operational functions of virtual power plant system.

systems. As a result, a VPP can obtain an additional program such as V2G and DR. The participation of the VPP could be considered as ancillary services in a power grid [23, 24]. The participants of the VPPs play roles as active consumers or prosumers, not passive consumers. In this case, energy markets can be liberalized. Also, the VPP manages the generation, storage, and demand source, and trades information regarding participants. Through this information, the VPP can forecast the DER's generation and demand.

If VPPs are constructed by regions, then extra-power can be produced. EV charging infrastructure by region is essential for EV supplementation [25-27]. Stability of a power system by regional VPPs can realize V2G technology. In short, a VPP application can maintain the reliability and stability of a power system using DERs. In addition, new profit can be obtained through extra-power such as market liberalization, V2G, business models, and so on.

\section{Conclusions}

The use of renewable energy sources and energy storage systems is increasing while fostering new policies for energy industries. Changes in power systems from centralized power systems to distributed power systems include sustainable and eco-friendly RES, emergency generators, and energy conversion and savings. However, DERs can cause instability and unreliability of power grids, and there is a lack of business models permitting general consumers to participate in the wholesale and retail markets for profit.

In order to solve these problems, we investigated DR and ancillary services in the USA and UK. In those cases, we found that DERs are used as ancillary services or alternative energy during load reduction or shedding at the DR. Demand resources are also used as ancillary services. This means that power demanders participate in power system operations through their generation and demand resources in wholesale and retail markets. As we have shown, The VPP can be a solution for the utilization of DERs and demand resources in a power grid. The VPP links several types of distributed generation into one power plant, and makes their participation on DR and ancillary services for reserves and frequency regulations in power grid.DERs provide frequency regulation services at a certain grid status, and supply 
energy during operating DR programs. In addition, DERs and demand resources could supply energy to EV charge infrastructure, and it is thus helpful to develop V2G-related technology.

Therefore, we suggest the creation of an EV market development plan. In such a plan, the operation of DERs and ESS are optimized according to demand characteristics of different consumers in the agricultural, residential, industrial, or commercial domain, or on campus. Second, various types of resources are linked by a VPP system for the power supply. Third, demand resources can participate in power supplies through DR and an ancillary service program in power systems. Fourth, a V2G application is applied to EV charging and discharging from DERs, ESS, and the DR. Fifth, a new V2G business model is developed through these all functions for the VPP.

Consequently, it is necessary to supply a VPP with DR and ancillary services that have been operated abroad so as to secure the reliability of the power grid and to expand distributed generation. This would positively promote the RES and EV supply in the Korean electricity market as well as promote the stable operation of power grids.

\section{References}

[1] D. Kathan, R. Aldina, M.P. Lee, L. Medearis, P. Sporborg, M. Tita, D. Wight, A. Wilkerson, "Assessment of Demand Response \& Advanced Metering STAFF REPORT," Federal Energy Regulatory Commission, 2012.

[2] A. Faruqui, R. Hledik, S. S. George, J. Bode, P. Mangasarian, I. Rohmund, G. Wikler, D. Dhosh, S. Yoshida, "A National Assessment of Demand Response Potential," Federal Energy Regulatory Commission, 2009.

[3] Mapping Demand Response in Europe Today of SEDC, http://www.smartenergydemand.eu/?p=653 3

[4] Demand Response Availability Data System (DADA) Phase I \& II Final Report, North American Electric Reliability Corporation, http://www.nerc.com/pa/RAPA/dads/Pages/default.aspx

[5] Korea Electric Power Corporation (Demand Side management), http://www.kepco.co.kr/dsm/

[6] Korea Power Exchange (Demand Resource Market), http://dr.kmos.kr/main/market_01.htm

[7] Electric power statistics information system of Korea Power Exchange, http://epsis.kpx.or.kr/

[8] National Grid for Balancing Services, http:// www2.nationalgrid.com/uk/services/balancing-services/re serve-services/
[9] Resources Subcommittee(RS) of North American Electric Reliability Corporation, http:// www.nerc.com/comm/OC/ Pages/RS/Resources-Subcommittee.aspx

[10] Demand Response Subcommittee of PJM, http://www.pjm.com/committees-and-groups/subcommit tees/drs.aspx

[11] P. Siano, "Demand Response and smart grid - A survery," Renewable and Sustainable Energy Reviews, vol. 30, pp. 4161-478, 2014.

[12] J.A. Lopes, N. Hatziargyriou, J. Mutale, P. Djapic, N. Jenkins, "Integrating distributed generation into electric power system : A review of drivers, challenges and opportunities," Electric Power System Research, vol. 77, pp. 1189-1203, 2007.

[13] Muljadi, E., Parsons, B.: Comparing Singe and Multiple Turbine Representations in a wind Farm Simulation. European Wind Energy Conference, NREL/CP-50039510, 2006.

[14] S. Letendre, K. Gowri, M. Kintner-Meyer, R. Pratt, "Intelligent vehicle charging benefits assessment using EV Project data," Richland, WA: Pacific Northwest National Laboratory, 2013.

[15] O. Palizban, K. Kauhaniemi, J.M. Geurrero, "Microgrids in active network management - Part I: Hierarchical control, energy storage, virtual power plant, and market participation," Renewable and Sustainable Energy Reviews, vol. 36, pp. 428-439, 2014

[16] Quadrennial TECHNOLOGY REVIEW 2015, Chapter 3: Enabling Modernization of the Electric Power System, http://energy.gov/ quadrennial-technology-review-2015.

[17] B. Wille-Haussmann, T. Erge, C. Witter, "Decentralised optimisation of cogeneration in virtual power plants," Solar Energy, vol. 84, pp. 604-611, 2010.

[18] T.H. Jin, M. Chung, K.Y. Shin, H. Park, G.P. Lim, "Real-Time Dynamic Simulation of Korean Power Grid for Frequency Regulation Control by MW Battery Energy Storage System," Journal of Sustainable Development of Energy, Water and Environment Systems, 4(4), pp. 392-407, 2016.

[19] J. D. Castillo, G. P. Lim, Y.B. Yoon, B. H. Chang, "Application of Frequency Regulation Control on the 4MW/8MWh Battery Energy Storage System (BESS) in Jeju Island, Republic of Korea," J. Energy Power Sources, vol. 1, pp. 287-295, 2014.

[20] L. Sigrist, E. Lobato, L. Rouco, "Energy Storage System providing primary reserve and peak shaving in small isolated power system: An economic assessment," Electrical Power and Energy System, vol. 53, pp. 675-683, 2013 
[21] A.G. Zamani, A. Zakariazadeh, S. Jadid, "Day-ahead resource scheduling of a renewable energy based virtual power plant," Applied Energy, vol. 169, pp. 324-340, 2016.

[22] P. Faria, T. Soarea, Z. Vale, H. Morais, "Distributed generation and demand response dispatch for a virtual power player energy and reserve provision," Renewable Energy, vol. 66, pp. 686-695, 2014.

[23] H. Marzooghi, G. Verbic, D.J. Hill, "Aggregated demand response modelling for future grid scenarios," Sustainable Energy, Grids and Networks, vol. 5, pp. 94-104, 2016.

[24] K. Christakou, "A unified control strategy for active distribution networks via demand response and distributed energy storage systems," Sustainable Energy, Grids and Networks, vol. 6, pp. 1-6, 2016.

[25] J. Aghaei, A. E. Nezhad, A. Rabiee, E. Rahimi, "Contribution of Plug-in Hybrid Electric Vehicles in power system uncertainty management," Renewable and Sustainable Energy Review, vol. 59, pp. 450-458, 2016.

[26] A. Ghasemi, S.S. Mortazavi, E. Moshhour, "Hourly demand response and battery energy storage for imbalance reduction of smart distribution company embedded with electric vehicles and farms," Renewable Energy, vol. 85, pp. 124-136, 2016

[27] E. Xydas, C. Marmaras, L.M. Cipcigan, "A multi-agent based scheduling algorithm for adaptive electric vehicles charging," Applied Energy vol. 177, pp. 354-365. 2016.

\section{저 자 소 개}

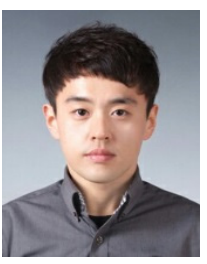

\section{진 태 환 (Tae-Hwan Jin)}

He received the B.S. degree in Electrical Engineering from Yeungnam University, Korea in 2015. He is currently pursuing the M.S. degree of Mechanical Engineering in the same university. He is interest in the modeling of renewable energy system and real-time power system analysis for the various power market development and operation.

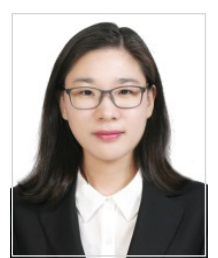

\section{박 혜 리 (Herie Park)}

She received the Ph.D. degrees in electrical engineering from University of Cergy-Pontoise, France and Yeungnam University, Korea in 2013. From 2013 to 2014, she was a post-doc researcher of Laboratoire de Mecanique et techmologie at Ecole Normale Superieure de Cachan, France. She is currently a research professor with the Automotive Lighting LED-IT Convergence Education Program at Yeungnam University. Her current research interests include building energy management, energy system modeling, parameter estimation, and regulations.

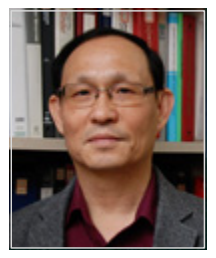

\section{정 모(Mo Chung)}

$\mathrm{He}$ is full Professor at the School of Mechanical Engineering, Yeungnam University from 1992. He received the Ph.D in Mechanical Engineering, UCLA (1990), BS (1980) and MS (1982) in Mechanical Engineering, Seoul National University. His research interests involve efficient utilization of energy and energy grid which is extended concept of Smart Grid encompassing both electrical and thermal energy.

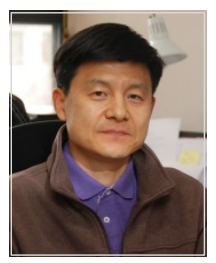

\section{신 기 열 (Ki-Yeol Shin)}

$\mathrm{He}$ is assistant Professor at the School of Mechanical Engineering, Yeungnam University. He received all of B.S. (1993), M.S.(1995) and Ph.D.(1995) degrees from Yeungnam University majoring mechanical engineering. His specialty is heat transfer, energy system, and mechatronics design. He had experienced in the in industrial field over 14 years and joined a faculty member of Yeungnam University in 2014. He has been teaching and conducting industrial research focused on the mechatronics system such as Power Plant, Power Generator, System Controller, and its modeling. He is working as manager of several projects in the Energy System Analysis and Power System Modeling. 


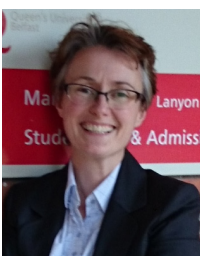

\section{Aoife Foley}

She joined Queen's University Belfast (QUB) as a Lecturer in September 2011. She graduated from University College Cork (UCC) with a BE (Hons) in Civil \& Environmental Engineering (1996) and a $\mathrm{PhD}$ (2011) in Energy Engineering. She has an MSc in Transportation Engineering (1999) from Trinity College Dublin. She has 12 years industrial experience in Siemens, ESB International, SWS Energy and Project Management Group.

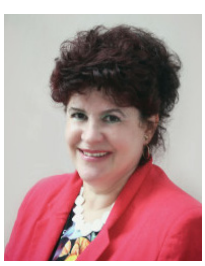

\section{Liana Cipcigan}

She is Reader at Cardiff University's School of Engineering, Centre for Integrated Renewable Energy Generation and Supply. She has previously worked at Durham University as a Research Associate, at Alberta University, Canada as a Research Fellow and at Technical University of Cluj-Napoca, Romania as a Senior Lecturer. Her research experience covers power system analysis and control, Smart Grids, Virtual Power Plants and DER integration in distribution networks. She has collaborated widely with industry, more recently during Royal Academy of Engineering secondment at National Grid, working in the Energy Insights department responsible for Future Energy Scenarios. 